\title{
Roles of Students' Council involvement in Management of Discipline in Public Secondary Schools in Bariadi District Council, Tanzania
}

\section{Hamis Lumanija, Demetria Gerold Mkulu}

Department of Education Foundation, Saint Augustine University of Tanzania, Tanzania

Received: 08 Nov 2020; Received in revised form: 11 Dec 2020; Accepted: 19 Dec 2020; Available online: 31 Dec 2020

(C)2020 The Author(s). Published by Infogain Publication. This is an open access article under the CC BY license

(https://creativecommons.org/licenses/by/4.0/).

\begin{abstract}
The study aimed at investigating the contribution of students' council in management of students discipline in public secondary schools in Bariadi District, Tanzania. The study employed mixed research approach with a convergent parallel design. Quantitative data were collected using questionnaires while interview and focus group discussion were methods used to collect qualitative data. The study included 04 heads of secondary schools, 04 discipline teachers, 74 teachers, 40 members of students' council and 94 students. The quantitative data was descriptively analyzed with the help of SPSS version 20 while thematic analysis was employed in analyzing qualitative data. The study established that students' council play a significant role in managing students' discipline through promoting healthier leadership, enforcing school rules and behavior and being role model for positive behavioral change among students. The findings further revealed that students' council was highly involved in enforcing school rules and regulations while less involved in decision making on disciplinary matters and punishing misbehaving students. The study recommended that government through the ministry of education should make sure that there are policy change to allow school management involve students' council in making decision basically students discipline in secondary schools.
\end{abstract}

Keywords - Roles, Students’ Council, Management, Discipline, Public Secondary Schools.

\section{INTRODUCTION}

This study examined the influence of students' council in management of discipline in public secondary schools in Bariadi District Council, Tanzania.

\section{BACKGROUND TO THE STUDY}

Discipline in schools for a long time has been a topic of discussion which needs more attention from different education stakeholders such as parents, donors, teachers' international organizations, and community from different corners of the world. Indiscipline cases have been increasing tremendously from day to day therefore, its management needs keen approach in which heads of schools and their staffs cannot fulfill (Kamau 2017). In other words, stakeholders currently focus on correcting deviant behavior and reinforcing desirable discipline among students in secondary schools so that secondary schools can be safe and healthy places for the creation of critical and creative school leavers who can deal with the needs of the society effectively.

Similarly, Kennedy (2018) in his study on managing student discipline through student leadership in Kenyan secondary schools; argues that discipline is considered one of the essential characteristics of an effective school; hence, there has been a growing debate on how to create positive school culture in which students can grow and develop morally. Therefore, in order to ensure that there is effective discipline

ISSN: 2456-7620 
management in schools; school leadership should decentralize some roles to students so that they can help in overseeing discipline matters in their secondary schools.

Woods (2005) in London also viewed that, the main role of student councils as set in the Education Act is promoting the interests of the school and the involvement of students in the affairs of school in co-operation with the board, parents and teachers. Discipline is one of the school affairs that require involvement of students in making decisions. Therefore, if students are involved in the management roles it makes reporting and dealing with disciplinary issues in schools more easy and efficient because students are likely to identify both desirable and undesirable behaviors among themselves than teachers and school management as a whole given the fact that they share a lot among themselves secrets that teachers cannot know, unless otherwise.

In order to decentralize effectively roles related to discipline management, school management is encouraged to embrace student leadership and councils so that students can play an active role in managing not only discipline but also other matters that are deemed to be significant for school prosperity (Mukiti, 2014). Thus, student councils are forums through which issues affecting students' welfare like discipline can be communicated between school management and students. Kambuga and Omollo (2017) suggest that, student leadership or rather councils give students opportunities, support and encouragement to express their voices pertaining to their welfare in schools as active members of the school community. Literature (Mukiti 2014; Kambuga and Omollo 2017; and Kennedy, 2018) show that large number of secondary schools and other educational institutions have been exercising in various situations to incorporate student voices when making decisions on issues concerning schools' development.

In United States of America, issues pertaining students' councils involvement in management of secondary schools such as management of discipline, planning school development activities, formulating by laws, rules and regulations which appear to be compatible with the goals towards the attainment of quality education (Alexander, 2017). Likewise, European countries experience several problems related to poor involvement of students' voice in management discipline issues in secondary schools. In England for instance, there is lack of clarity among policy makers and schools regarding the purpose of provision for pupils voice (Whitty and Wisby, 2007).

ISSN : 2456-7620

https://dx.doi.org/10.22161/ijels.56.72
Similarly, in Austria and Slovenia, secondary schools have practical experience in collection and use of student voices in any decision made in schools. It is an imperative requirement of the law in European countries such as Switzerland and Finland to consider student councils when making decision on matters concerning students' welfare (Cato, 2018). For example, in 1999 United Nations supported a Millennium Young People's Congress of more than 600 children from more than 100 countries who gathered in Hawaii to discuss and assess issues concerned their future life including access to education and how schools value their voice before making decision in the globalized world (Lansdown, 2001).

In Africa, most of the Sub Saharan countries face lot of problems pertaining to involvement of students' councils in making decision about school development plans including management of school discipline. In South Africa for instance, it is reported that the emphasis for students right to participate in the process of democracy in schools, their activities and voices still is not given the attention they merit (Nishiyama, 2017). Likewise in Nigeria, it is said that, students' government is not given the required value in management of school discipline. Students in most of the secondary schools face indisciplinary behaviors such as truancy, stealing, examination malpractice, sexual immorality and substance use that hinder them from attaining quality education (Usman, 2016).

In Tanzania, the practices of students' council participation in management of school discipline in public secondary schools can be traced through experience and studies which were previously done in the country. The Education Act no. 25 of 1978 and its amendments no. 10 of 1995 and 2002, the Education Training Policy of 1995 and the Child Act no. 21 of 2009 among others are some of the government documents that legalize the establishment of students' council in the education systems in Tanzania including secondary schools (URT, 2014). Based on experience, the education system and the government of Tanzania embrace student councils in all levels of education. Precisely, student councils, committees and leadership are experienced in public and private education institutions in which student leaders are elected through votes and others are appointed by the school management.

The major role of establishing students' leadership structure in schools is to empower students in realizing their potentials in leadership and overseeing their welfare including disciplinary matters. However, the roles and effectiveness of 
students' council in influencing management of discipline in public secondary schools in Tanzania is still questionable. This is based on the fact that, despite the presence of these councils, secondary schools continue to experience deviant behaviors among students including but not limited to examination dishonesty, dropout and truancy, improper school uniforms, sexual abuse and strikes (Mukiti, 2014; John, 2017; Kennedy, 2018).

Similarly, Shija (2016) in his study on My Right, my Voice in Tanzania reports that students' councils in secondary schools are statutory requirement in every school though most the time students' leaders are usually appointed by teachers and effectively represent the interests of students which is the main goal of the forums in schools. These in turn contribute to poor students' education attainment and destroy reputation of teachers to the school as whole. Despite these detrimental effects, studies on this problem are limited in Tanzania especially in Bariadi District Council. In other words, the essence of students' councils and other forums that intend to encourage students' voices to be held and supported in disciplinary matters is well known. Therefore, the current study intended to examine the influence of students' council on management of discipline in public secondary schools in Bariadi District Council in Tanzania.

\section{STATEMENT OF THE PROBLEM}

Discipline is a cornerstone of school welfare. In other words, schools with disciplined students grow, develop and perform better than schools with students who exhibit unethical conducts. Thus, discipline in schools need to be overseen based on the formulated and agreed standards. In most cases school discipline is established through the government bodies, school boards, school committees and parents and teachers association that are entrusted to deal with any type of irregularities. It is hoped that, the presence of these disciplinary forums and organization can help to remedy the deviant behavior in schools.

However, schools continue to experience indiscipline cases among students including, but not limited to substance abuse, truancy, lack of punctuality and improper school attire. This situation might have been attributed to the way student government is obtained. School management in most cases has been nominating leaders on behalf of students instead. This process has deprived the rights of students to exercise democracy on obtaining the kind of leaders they like. Also, the nominated leaders lack confidence, creativity, respect, management skills and royalty (Mnubi, 2015). On the other hand, when students are not involved in the decision making process they see no meaning of participating in school discipline and thus the discipline matters is left on the shoulders of school management.

Despite the important role played by students' council in facilitating students' involvement in decision making in secondary school environment, secondary school discipline management in Bariadi district council is a serious issue. If this situation is not settled, there is a possibility of losing future generation leaders of the society and in turn may increase the number of graduates who are less productive hence, an increased social tensions in the society. Therefore, the current study, examined the influence of the students' council in management of school discipline in public secondary schools in Bariadi District Council.

\section{SIGNIFICANCE OF THE STUDY}

The findings of the proposed study informed policy makers to redesign and implement new legal frame works that could foster desirable discipline among students in secondary schools. Likewise, the results of this study had the potential to inform education leaders like heads of schools to think about best practices towards empowering students' councils so that they can engage in discipline management effectively.

The study creates awareness to teachers about issues related to discipline such as factors for unethical behavior in schools from which they can develop good effective strategies not only to discourage undesirable discipline but also to reinforce good discipline among students. Additionally, the findings of this study provide student leaders and students body at large an understanding about the worthiness and consequences of desirable discipline and indisciplinary practices respectively.

\section{LITERATURE REVIEW}

This chapter presents a literature review based on one objective. Studies of other scholars were reviewed to comprehend and investigate the research problem. The researcher reviewed the theoretical literature which enabled to study a theory related to the topic and again clarity of the research topic. The empirical literature justified the need for the study and highlighted the relationship between the past and the current study. 


\section{Theoretical Literature Review}

Theoretical framework refers to a set of theories which act as background and guide to the investigation of the problem; it gives the relationship between the variables (Creswell, 2014). The current study on influence of students' council on management of discipline in public secondary schools is based on Path- Goal Theory (PGT) which was propounded by House and Mitchell in 1974. The theory is based on leader-follower concept and relationship that a leader shows the way for the followers to act upon institutional activities (Murage, Mwaruvie \& Njoka, 2017).

Similarly, Ratyan, Khalaf and Rasli (2013) assert that pathgoal theory is classified under contingency approach that it can be applied in different situation and times by the same leader and that leadership behavior like directives, supportive, participative and achievement based have a positive effect on the subordinates and pave the way for achieving pre-determined organizational goals. In other words, leaders are role models for the followers to observe and imitate on what leaders are doing.

Thus, good leadership results into obedience, participative and goal-focused subordinates while poor leadership may result into poor organizational culture. In other words, the theory tries to relate the leader's behavior and followers' behavior.

In this regard, path-goal theory relates to the current study in the sense that members of the students' councils are studentleaders either elected or appointed to represent others in a school in showing the way for achieving accepted behaviors in schools. They are supposed to exhibit good behavior for their fellows to learn from them in different situations. Thus, students' council are that comprise exemplary members who are able to identify critical leadership roles and behavior suitable to their schools and are likely to be powerful in management of discipline among students than those in which the members are careless and undetermined.

Based on this theory, Murage et al (2017) argued that student leaders helped to remove all forms of indiscipline like bullying, laziness and substance use by guiding and supporting fellows in health social relationship and communication, team work and being good examples. This promoted virtues among students which in turn promoted good performance which was the ultimate goal of any student in a given learning situation. In this regard, path-goal theory served not only as a framework for selecting students both to constitute the students' councils and participate in this study but also it guided data analysis, discussion of findings and conclusion of this study. That is to say. The theory helps in indicating how the findings reflect or deviate from it.

The theory is based on the fact that it is the basis for leaders to help remove obstacles by showing the right way to the followers for achieving pre-determined institutional goals through engaged workforce (Farhan, 2018). Thus, the findings implied that members of student critically on understanding their behaviors first before enforcing mechanisms to improve discipline among students. It indicates how leaders' disciplines affect followers' discipline.

However, the path goal theory fails to obey the principal of specifying meaning that it consists of many aspects of leadership which mislead leaders consequently followers (SAGE, 2016). SAGE adds that the theory insists much on guiding, helping and supporting followers of which some followers may become dependent on their leaders. This resulted into challenges in fulfilling organization activities to achieve pre-determined goals. Despite these critiques, the current study benefited much from the theory specifically on the effectiveness of students' council in managing.

\section{Empirical Literature Review}

For the intention of the study on the roles of students' council in discipline management in public secondary schools in Bariadi district council, literatures global, regional and national wise were reviewed on the following headings: roles played by students' council in management of discipline in public secondary schools.

\section{Roles of Students' Council in Discipline Management}

Based on literature reviews, student councils were involved in different situations to make decision on issues concerning school development including; formulating and enforcing school rules and regulations, planning and managing school activities and solving disputes are among the roles played by student councils in management of students discipline in schools.

\section{Formulation of School Rules and Regulations}

In Ghana, Asare, Mensah, Prince and Gyamera (2015) studied on procedures involved on how teachers do through their perspective roles in managing discipline and how students perceive such involvement. The study found that, teachers used judgmental approach to subjective behaviors 
of students and evaluated disciplinary measures to interpret as the way to stop misbehaviors in schools. The study recommended that teachers should indoctrinate the behaviour of including students in rules setting so as to enhance ownership of the rules in order to inspire them take responsibility measures for their own behaviors. Therefore, Teachers and educators should see the importance of corrogolating their students in establishing, implementing and controlling the rules in the welfares of their life at school.

Furthermore, a study by Usman (2016) conducted on the impact of students' indiscipline on management of secondary schools in Nigeria. The study indicated that truancy and examination malpractice was among the challenges on management of secondary schools in Nigeria. This was observed that the government lacked active laws, rules and regulations that could stop malpractices of examinations and other indiscipline issues in their schools. The study recommended that, ministry of education should involve students working towards the eradication of examination malpractice in schools. In other words, the situation showed that there was no way a student can be left behind for any means in school for one dealing with discipline issues in school including formulation of rules and regulations in schools.

Apart from that, a study by Kennedy (2018) conducted in Kenyan secondary schools revealed that student councils were involved in formulating school rules and regulations that geared towards managing discipline in schools. This implied that members of the student councils were charged with the role of thinking critically on the laws, regulations and rules that promoted virtues among students. The study recommended that capacity building is important to members of the student councils so that they actively participated in the formulating school rules and regulations.

In addition to that, a study by Kamau (2017) on the influence of students' council involvement in management of students' discipline in public secondary schools in Kenya found that student councils were charged with the role of formulating school rules and regulations. In other words, members of the student councils should make sure that they participate in formulating school rules and regulations that fostered good behavior among students. Thus, the study recommended that school management should provide opportunity for members of the student councils to participate in formulating school legal frameworks which in turn fostered implementation.
Similarly, Murage (2014) in Kenya studied the influence of student councils on the management of discipline in secondary schools. The findings of this study demonstrated that student councils were responsible for promoting school rules and regulations towards enhancing ethical behaviors among students. Students' councils are instrumental organ that is required to articulate the discipline of students on behalf of the school management; thus, teachers have the obligation to incorporate students' leaders since they are the first witness of the misconduct of students. This allegation is contrary in Bariadi secondary schools where teachers select leaders but unfortunate they do not empower them as required.

\section{Planning of School Activities}

Wallach (2006) studied on student voice with emphasizing much on the potential relationships, relevance and rigor in small schools in Washington, USA. The study wanted to assess aspects of development of small schools and the associated processes of change using three principles of rigor, relevance and relationships. The study reported that for a long time, America's education system has been undergoing reforms of how education should be treated and practiced in the area; the exercise has been basing on adults without consulting at any point the students' views that ultimately benefit from the reforms. This is to say, effectiveness of any changes need to involve students since they are the ones who are expected to benefit from the changes. Participating students in decisions concerning their learning brings about very results in students achievements and the school at large.

Mbonyonga (2018) examined the role of student representative councils in curbing students' riots in secondary schools in Zambia. The study adopted descriptive case study design. The findings of this study demonstrated that students' councils were forums through which students through representatives were involved in decision making about school route and activities. This helped to create a sense of ownership towards school routines and therefore had a positive effect on management of students' discipline. The study recommended that the government through the ministry of Education the government should create awareness on the essence of students' voice in school leadership, management and administration.

Similar results were reported in a study by Nekesa (2018) who conducted a study to explore roles of students' councils in enhancing discipline in public secondary schools in Likoni 
Sub-County Mombasa County Kenya. The findings demonstrated that students' councils were involved in planning and supervising the implementation of school activities which in turn promote discipline and sense of belonging among students. In other words, if members of the students' councils were involved in all stages of planning and implementation of school activities makes the supervision by these leaders more easy and students can easily obey instructions from students' leaders.

\section{Enforcing School Rules and Regulations}

Students' councils are also charged with the role of enforcing school rules and regulations. A study by Amoah, Francis, Laryea and Abena (2015) assessed on procedures involved by teachers to carry through their respective roles in managing indiscipline and how students perceived such involvement in Ghana. The study reported that, teachers used judgmental to subjective behaviors as well as evaluating the disciplinary measures to interpreting it as the appropriate measure to stop misbehavior. In other words, students' councils are essential in developing and making sure that school regulations are adhered for the welfare.

A study by Kyalo (2017) examined the influence of student councils' involvement in school governance on students' discipline in public secondary schools in Kenya. The results indicated that students' councils played a significant role in enforcing the implementation of school rules and regulations. The study further reported that schools in which student councils were not involved in management of students discipline experienced high levels of students' indiscipline. Likewise, without students' councils, enforcing regulations may be jeopardized.

Mukiti (2014) also conducted a study on role of students' council in secondary schools management in Kenya. The findings demonstrated that, students' councils were responsible for ensuring that students obey school rules, regulations and instructions decided and approved by the school management. The study added that, members of the students' councils were charged with the role of punishing other students in case of minor indiscipline cases like speaking vernacular languages and noise making. Thus, there should be thorough preparation of student councils if effective performance by these councils in management of discipline was to be achieved.

\section{RESEARCH METHODOLOGY}

\section{Research Approach}

According to Gray (2014) research approach is a plan and the procedure for research that span the steps from broad assumption to detailed methods of data collection, analysis and interpretation. This study employed mixed research approach whereby both quantitative and qualitative data were collected using different methods. Creswell (2014) describes mixed research approach as one of the research approaches in which a researcher collects analyses and mixes both qualitative and quantitative data in a single study.

This approach enabled the researcher to obtain data in form of numbers and explanations which were crucial in informing educational stakeholders a valuable change in education than if only single approach was employed.

\section{Research Design}

This study adopted mixed methods research design under which convergent parallel design was employed to collect data on the "roles of students' council in management of school discipline in public secondary schools in Bariadi District Council". Demir and Pismek (2018) defined convergent parallel research design as a process where a researcher simultaneously collects quantitative and qualitative data simultaneously and then analyses the data differently and merges them during the interpretation and discussion in order to triangulate the research findings.

Convergent parallel design was used because it helped the researcher to gather two types of data at once and it was a manageable process. Creswell (2012) is of the view that convergent parallel, mixed methods is a type of design in which both qualitative and quantitative data are collected concurrently and analyzed separately and then merged together at the end of the study. Therefore, quantitative data were gathered through questionnaires, while qualitative data were collected through in-depth interview and focus group discussion.

\section{Research Area and Rationale}

This study was conducted in public secondary schools located in Bariadi District Council. Bariadi District Council is one of the six District Councils of Simiyu Region. The other districts are Meatu District Council, Maswa District Council, Itilima District Council, Busega District Council and Bariadi Town Council. It is located in north of Tanzania and South East of Lake Victoria lying between latitude $2^{0} 15^{\mathrm{I}}$ and $2^{0} 15^{\mathrm{I}}$ South of Equator and longitude $33^{\circ} 40^{\mathrm{II}}$ and $35^{\circ} 10^{\mathrm{II}}$ East of Greenwich (William, 2017). 
It is bordered by Busega District to the west, Bunda and Serengeti Districts to the west, Maswa Game Reserve to the east, Maswa and Itilima Districts to the south. Bariadi District Council has 23 secondary schools of which 22 are public secondary schools and 1 is privately owned. The rationale behind the choice of Bariadi district as the study area was based on the fact that the existed literature showed that there had been no study conducted to find out the role played by students' councils on discipline management in public secondary schools. The other reason was based on the principle of familiarization that the researcher is familiar with the area but avoided personal subjectivity towards the information given by the respondents. This is based on Creswell (2012) that the problem can be efficiently studied if the researcher has an understanding of both the respondents and the research area.

\section{TARGET POPULATION}

A target population is group of individuals, elements or subjects which a sample is to be drawn and to which the researcher wishes to draw conclusion or generalize the results (Namala, 2015). In other words, a target population is a group of individuals from which data was gathered and to which inferences about the problem were made. The population of the study comprised of all heads of secondary schools, all teachers, all students and all public secondary schools in Bariadi District Council, which is approximately 1911. This population was considered adequate to provide key information pertinent to the objectives of the study.

\section{Sampling Procedure}

A sample is group of respondents drawn from population in which the researcher is interested in gaining information and drawing conclusions (Ezzy, 2002). According to Mulegeki (2014) researchers often select samples because it is difficult to study the whole population in a single study. Based on aforesaid definitions, both probability and non probability techniques were employed to obtain the sample size of the study. In probability sampling, stratified random sampling and simple random sampling techniques were used to select schools, teachers and students to participate in the study.

\section{Sampling of Schools}

The researcher employed simple random sampling technique to sample the schools which took part in the study. Pieces of papers labled $\sqrt{ }$ with names of schools and $X$ with names of schools were folded and mixed thoroughly. The researcher then picked only one piece of paper with replacement. The ISSN: 2456-7620 papers labled $\sqrt{ }$ gave the names of the 4 schools which participated in the study. This sampling technique was adopted because it increased the probability that every school could be selected to participate in the study and it also helped to minimize biasness.

\section{Sampling of Teachers}

The study sampled 74 teachers. These participants were sampled through stratified random sampling and simple random sampling techniques. The researcher grouped the participants into two strata based on gender, and then from each stratum, simple random sampling technique was employed. Each school was to give a sample of 18 teachers; however, there was a great disparity in the number of teachers from the sampled schools. Based on this unevenly distribution of teachers in the sampled schools, the researcher sampled 36 teachers from school A \& B respectively (18 teachers from each school) while 38 teachers were sampled from school C \& D (19 teachers from each school). This gave a total of 74 teacher respondents who took part in the study.

\section{Sampling of Students}

The researcher adopted both stratified and simple random sampling techniques to obtain a sample of 94 students from the 4 sampled public secondary schools. A similar process as that of teachers was employed to obtain the sample. The researcher sampled 48 students from school A \& B (24 from each schools), while 46 students were sampled from school C \& D (23 from each school).

On the other hand, the researcher employed non probability sampling technique basically procedure was employed when sampling heads of schools, discipline teachers and student leaders. Non probability sampling involved selecting individuals to participate in the study based on zero probability instead focuses on judgment made by the researcher (Sharma, 2017).

\section{Sampling of Heads of Schools, Discipline Teachers and Students' Leaders}

Purposive sampling technique was adopted to obtain 4 heads of schools, 4 discipline teachers and 40 student leaders based on the fact that they are key informants because of the position they occupy and the roles they play in dealing with discipline matters in schools. It wanted to understand the experiences in the influence of students' council on management of discipline in public secondary schools in Bariadi district council. Yin (2011) describes purposive sampling technique as a procedure for selecting participants 
who are likely to provide more relevant data about the problem.

According to Creswell (2009) sample refers to the population that is observed. A sample helps in making inductive reasoning in which observation is made to the sample and the conclusion is generalized for the entire population from where the sample was obtained. Charles

Table1: Sample size of Participants $(N=216)$

\begin{tabular}{|c|c|c|c|c|}
\hline \multirow[t]{2}{*}{ Categories } & \multirow[t]{2}{*}{ Target population } & \multicolumn{2}{|c|}{ Sample size } & \multirow[t]{2}{*}{ Sampling technique used } \\
\hline & & $\mathbf{n}$ & $\%$ & \\
\hline Heads of Schools & 22 & 4 & 1.9 & Purposive sampling \\
\hline Discipline teachers & 22 & 4 & 1.9 & Purposive sampling \\
\hline Teachers & 215 & 74 & 34.2 & $\begin{array}{l}\text { Stratified random \& Simple } \\
\text { random sampling }\end{array}$ \\
\hline Student Council members & 84 & 40 & 18.5 & Purposive sampling \\
\hline Students & 1,568 & 94 & 43.5 & Simple random sampling \\
\hline Total & 1,911 & 216 & 100.0 & \\
\hline
\end{tabular}

Source; Researcher`s, 2020

\section{DATA COLLECTION METHODS AND PROCEDURES}

This study adopted questionnaires, interview guides and focus group discussion guides as methods of data collection.

\section{Questionnaire}

Kothari (2004) defines a questionnaire as a method of data collection consisting of a number of questions either printed or typed in a definite order on a form. This study employed questionnaire as a method of data collection. The instrument had both open and closed questions. The instrument was administered to teachers and students in public secondary schools in Bariadi District Council. Questionnaires were used because it enabled the researcher to collect data from large sample within a short period of time. The instrument was prepared in line with the research objections that reflected its subsections.

\section{Interview}

According to Creswell (2012) interview is a method of collecting data in which a researcher asks questions to either one or more respondents and records the responses. This study employed interview to collect primary data from heads and Mertler (2002) aver that for descriptive research studies, a recommended sample is approximately $10-20$ $\%$ of the population. In regard to this $11.30 \%$ was used to obtain a sample of schools, head teachers, discipline teachers, teachers, and students. This information was summarized in table 1. of schools, discipline teachers and student leaders. In this regard, one- on- one in-depth and unstructured interview were used in this study. This kind of interview helped the researcher to elicit more information from the participants through the use of probing questions. Thus, participants' experiences, feelings and motives on the relationship between students' councils and discipline management in secondary schools can be realized. The content of the instrument was based on the research objectives.

\section{Focus Group Discussion}

Focus group discussion is a method of data collection in which a researcher interviews or asks questions to a group of participants at a time, and the participants must have a good and shared understanding with the research problem (Creswell, 2012). This study adopted focus group discussion to collect primary data from students' council members. Therefore, focus group discussion was conducted to 40 students' council members who were more experienced with school matters and the factors underlying their schooling as pinpointed by Frankfort- Nachmias (2015). Pacho (2017) commented that an effective focus group discussion should mainly comprise of 6-12 participants who share common 
characteristics. In this study, each session for focus group discussion comprised of 10 students' council members. This method of data collection enabled the researcher to obtain more and clear insights about discipline in schools and the role played by students' council.

\section{Pilot Study}

A pilot study was conducted to determine the effectiveness of the research instruments in tapping the desired information to answer the research questions. It involved pre-testing the developed research instruments to few participants to determine whether they enable the researcher to obtain reliable information to answer the research questions (Creswell, 2012; Kothari, 2004). Therefore, the pilot study was conducted at 1 public secondary school in Bariadi Town Council that was not included in the actual study.

In this regard 10 questionnaires were administered to 10 participants (5 teachers and 5 students). Additionally, 2 interviews were conducted to 2 heads of secondary schools. During the pilot study, the participants were asked to provide their views on the nature and arrangement of the items. Both, the results of the pilot study and the insights that were provided by the respondents were useful in modifying the research instruments so that they can be effective in collecting the desired information. This also helped in adjusting the instruments before the actual data collection.

\section{Validity of Research Instruments}

According to Zohrabi (2013) validity is the ability of a measuring tool measure what it is supposed to measure and performs the functions that purport to perform. Both face and internal validity of the study instruments were ensured through exposing them to experts and colleagues for scrutiny. Experts included the supervisor and panelists. Their insights provided a room for adjustments of the instruments so that they could be more efficient in collecting information that would be useful in explaining matters related to students' councils and discipline in schools.

\section{Reliability of Research Instruments}

Reliability is the extent to which an instrument produces consistent and reliable results over time and under comparable methodology or situations (Leung, 2015). It is the ability of the research instrument to produce stable results time to time when administered under comparable situations. In order to ensure reliability of the research instruments basically questionnaire, the researcher administered 10 questionnaires to 10 participants (5 teachers ISSN: 2456-7620

https://dx.doi.org/10.22161/ijels.56.72 and 5 students) at one of the public secondary schools located in Bariadi district. This school was excluded during data collection. The data from questionnaires were coded and entered into Statistical Packages for Social Sciences (SPSS) version 20 from which Cronbach alpha correlation coefficient was calculated and found to be 0.8 meaning that the instruments were highly reliable.

\section{DATA COLLECTION PROCEDURES}

Prior to the data collection, the researcher ensured that research instruments were well prepared and approved by the panelists. Thereafter, the researcher obtained a study permit from the Vice Chancellor's Office at Saint Augustine University of Tanzania. This letter introduced the researcher to the office of the Regional Administrative Secretary (RAS) and District Administrative Secretary (DAS) of Simiyu Region and Bariadi District respectively as well as to heads of schools. These authorities also issued study permits to legalize the process of data collection. After obtaining the research permits, the researcher consulted the participants including heads of schools, discipline teachers, students' leaders and students for official arrangements to ease the process of data collection. The researcher then went back to the respective schools on the agreed date and collected data.

\section{DATA RECORDING AND ANALYSIS}

Data recording, is a process in which information are either noted down or tapped in electronic devices like audio recorders so that they can be available (Creswell, 2012). In this regard, quantitative data were self recorded by participants in the spaces provided in the questionnaires. In addition, qualitative were recorded through field note book. These materials were made available prior to data collection.

On the other hand, data analysis is a process in which the collected data is made meaningful to readers for action (Creswell, 2012). The researcher employed descriptive statistics in analyzing quantitative data from questionnaires through the help of Statistical Packages for Social Sciences (SPSS) version 20 and were presented in form of frequencies and percentages so as to indicate the intensity of the issues related to student councils and discipline in schools.

The results from descriptive analysis were presented in tables and statistical charts such as pie charts and bar graphs. Similarly, thematic analysis was adopted for analyzing the qualitative data from interview and focus group discussion. 
Adams and Lawrence (2015) argue that, thematic analysis is a process in which main ideas in the respondents' responses are identified and common themes are then categorized together. Thus, the qualitative data were first transcribed and organized manually into major and recording themes based on the specific research objectives. The results were presented in form of explanations and narratives and quotations based on what was spoken by the participants during both interview and focus group discussion then supported with popular literature.

\section{ETHICAL CONSIDERATIONS}

Research ethics refers to a way through which a research can be conducted and report the findings in a moral and responsible manner (Charles, 2015). In other words, adhering to ethical principals helped to add credibility to the study. For that reason, the researcher asked for permission letters from the authorities involved in the study. These authorities included the Vice Chancellor at Saint Augustine University of Tanzania (SAUT), the RAS and DAS for Simiyu Region and Bariadi District respectively as well as consulting participants' prior to data collection.

Additionally, the researcher ensured confidentiality and anonymity by not disclosing the participants' identities. In this case, pseudo names like school $\mathrm{A}$ and participant $\mathrm{Y}$ were used in place of the real names of the schools and participants.

The researcher explained the purpose of the study and informed the participants that their participation in the study was on voluntary basis and they could stop participating anytime they wished to do so. Therefore, consent forms were prepared and given to participants for them to sign. Likewise, the researcher adhered to the principle of no harm. This means that, any research processes that may result into participants' harm and discomfort were avoided. For example, the researcher ensured that items in the research instruments and the probing questions were critically designed to avoid sensitive questions that could otherwise have negative impact on the wellbeing of the participants.

\section{RESULTS AND DISCUSSION}

This section presents and discusses the findings obtained from the field. The chapter begins with participants' demographic information. Thereafter, it presents and discusses the major findings based on the specific objectives. Pseudo names are used during presentation and discussion of findings collected through interview and focus group discussion.

Table 2: Distribution of Responses' Return Rate $(N=216)$

\begin{tabular}{lllll}
\hline Participants & Sample size & Instruments & Successful & Percent \\
\hline Teachers & 74 & Questionnaire & 74 & 100 \\
Students & 94 & Questionnaire & 94 & 100 \\
Head of schools & 4 & Interview & 4 & 100 \\
Discipline teachers & 4 & Interview & 4 & 100 \\
Students' council & 40 & Focus & group & 40 \\
Members & & Discussion & & 100 \\
\hline
\end{tabular}

Source: Field Data (2020)

\section{Roles Played by Students' Council in Managing Students' Discipline}

This section presents and discusses the findings for the first objective which intended to find out the roles of Students' Council in Managing students' discipline. The participants were asked to indicate the extent to which they either agree or disagree with the roles of students' council provided in Likert scale format. The findings are summarized and presented in figure 7 below; 


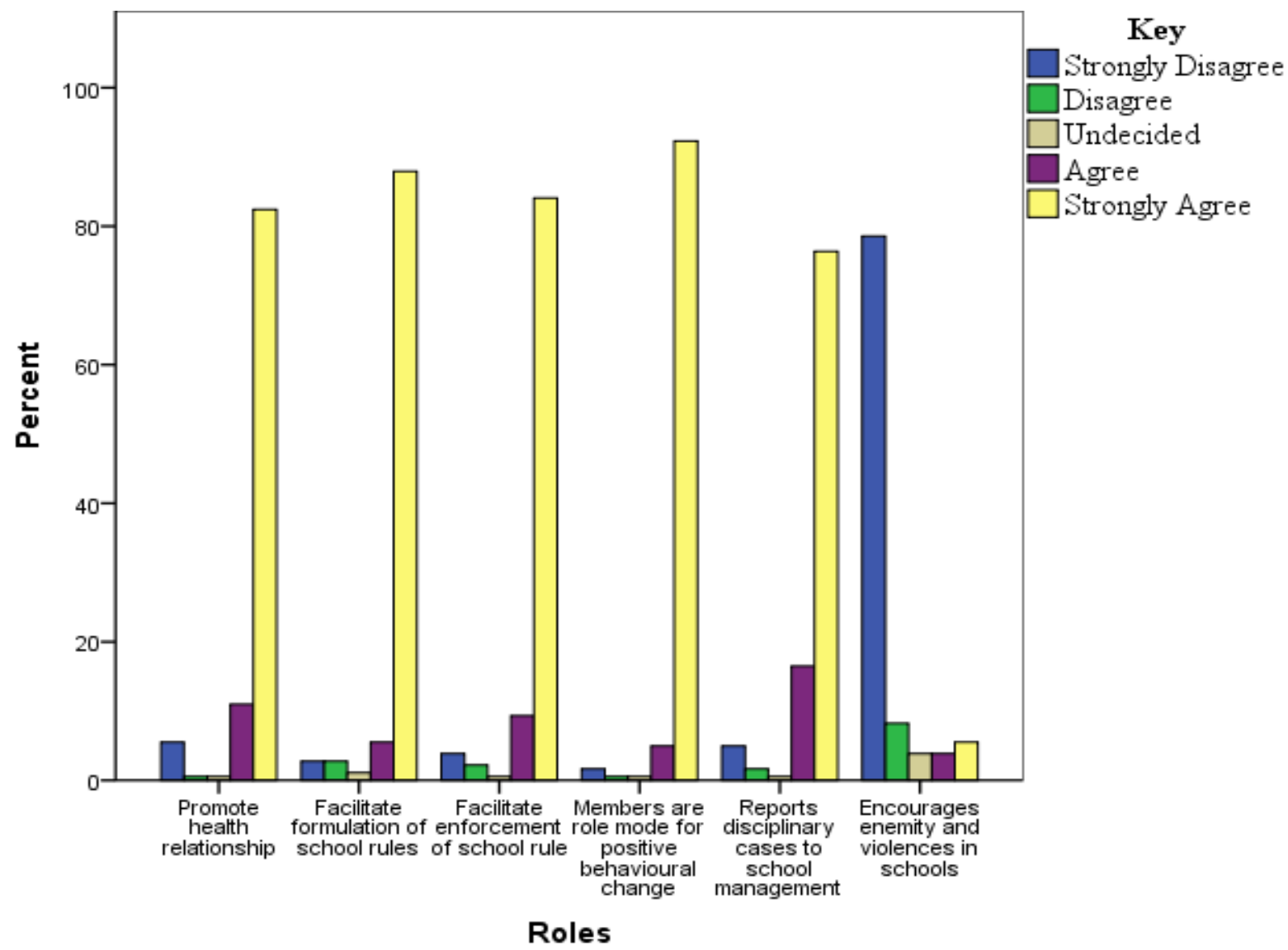

Fig. 1: Roles of Students' Council in managing students' discipline

\section{Formulation of School Rules}

The findings in the figure 1 demonstrate that 87.9 percent of the respondents strongly disagree that students' council is involved in formulation of schools rules, regulations and orders. At the same time 2.7 percent disagree with the statements while 1.1 percent was undenided. In addition to that 5.5 percent and 2.7 percent of the participants agreed strongly that students' council is responsible for the formulating school rules and regulations. Thus, majority of the participants indicated that students comments does not involve in discipline management.

This findings is in opposite with the findings collected through interview and focus group discussion. For instance, Discipline Teacher $\left(\mathrm{DT}_{2}\right)$ said,

We maximally call them when making tough decisions about discipline like discontinuing or suspending students who found to have done mistakes which violet school rules such as stealing other properties, fighting. Sometimes student themselves engage in punishing students who found done mistakes. We assemble student at parade and call students with mistakes in front of the students and get punished (Interviewee 2, $6^{\text {th }}$ August, 2020).

Additionally, during focus group discussion, Participant 12 spoke that, "Teachers involve leaders mostly when making school rules and orders and showing punishment to those who do not behave and live well with fellows". However, during focus group discussion, students were asked probing questions to determine whether they are involved in making school rules. Most of the participants denied that they do not formulate school rules but they only help to make sure school rules are followed by students. These findings are similar to those of Kaman (2017) and European Union (2018) who identified that schools can improve their learning environment to their students by listening to the voices of all its community including students.

\section{Enforcing School Rules}

ISSN : 2456-7620 
Based on the results in Table 6, 3.8 percent of the participants strongly disagree that students' council is involved in enforcing schools rules while 2.2 percent disagreed and 0.5 percent were undenied. Furthermore 9.3 percent and 84.1 percent of the participants noted agreed strongly that students' council is charged with the role of enforcing schools rules.

These findings denote that majority of the participants affirm that students' council is involved in enforcing school rules. Moreover, similar results were reported during both interview and focus group discussion.

To begin with the interview, Head of School $\left(\mathrm{HoS}_{1}\right)$ said that, "I also maximizing involving student leaders when a particular student is to be punished including suspension due to misbehaviors". $\mathrm{HoS}_{2}$ also narrated, "We involve students" council much in punishing and reporting students who are indiscipline. But their major responsibility is to ensure school rules are followed". In fact one respondent noted thus:

Student leaders participate to ensure students observe school rules. We use them to get reports of student with bad behaviors from the dormitory, dining hall, playgrounds, subject clubs session. Therefore, student leaders play a big part to ensure student obey school rules but they do not work alone, teacher on duty, discipline teacher matron and patron also are responsible people who work together with student leaders (Interview 1, $4^{\text {th }}$ August, 2020).

Similarly, $\mathrm{HoS}_{3}$ give a view that, "To a large extent, leaders in the student council involve in making sure that students follow school rules, orders and regulations while in classes, dormitory, dining hall, or other school environment". These findings are in line with Kyalo (2017) and Mukiti (2014), who reported that students' council is responsible for ensuring that schools rules are adhered by students. This means that students' council make other students understand and be responsible to school rules, regulations and orders.

\section{Role Model for behavioral change}

The findings in figure 1 shows that, 1.6 percent and 0.5 percent strongly disagree and disagree with the statement that, students are role model for positive behavioral change among students. At the same time 0.5 percent was undecided. Furthermore, 4.9 percent and 92.3 percent agreed and strongly agreed that the students council specifically members of that council are changed a role of being a role model for desired behavioural change among to students. During discussion with the students in Focus group discussion, one participant said:

As a leader, I am supposed to behave well so as other students can learn and behave good conduct. If a leader in a school does not have discipline, there is no way you can expect other students to have good discipline. Most of the time whether in the classes or elsewhere in the school environment a leader must be the example in order to simplify the correction of others (Participant 6, $4^{\text {th }}$ August, 2020).

Similarly, the findings concur with Murage, Mwaruvie and Njoka (2017) reputed that students' council are role models to students. In other words, behaving well is a result of social learning theory (Mgaya \& Kamugisha, 2019). In the same maaner, House and Mitchell Path Goal Theory also suggest that leaders are supposed to behave in an acceptable manner so that their followers can be behaving in the same manner (Murage, Mwaruvie \& njoka, 2017). That is to say students behave in line with the behaviour of their leaders. This is observational learning that if students see their representative behaving in a good manner they are attracted to act the same.

\section{Reporting Indisciplinary cases}

Figure 1 show that 4.9 percent of the participants strongly disagree that students report disciplinary cases while 1.6 percent disagree with such statement. Majority of the participants about 76.4 percent strongly agree that students' council is changed with a role of reporting indiciplinary cases to school management for further process. One of the participants in the interview said:

In most cases, student leaders report different indiscipline cases which are done by students. For example, it is very difficult for me to know every student's behavior in this big school, sometimes students fights win the dormitories, they steal school properties like chairs, books and others. Since leaders live with them elsewhere in the school ground, they get the information and bring them in my office. Therefore, student leaders help to investigate and prevent bad events that in one way or another may have caused by naughty students. I appreciate their work, thus their presence is of great important in running of this school (Interviewee 3, $8^{\text {th }}$ August, 2020).

\section{Promote healthy Relationships}


The results in figure 1 show that students' council is responsible for promoting good interpersonal relationships among school members. This was identified by the majority (82.4 percent) of the participants. Similar results were established by Griebler and Nowak (2011) that student's council is charged with a role of promoting relationships among school members. It enhances characteristics of warmth and acceptance among students and teachers (Nandeke, 2017). One participant during focus group discussion reported:

Students create good relationship between students, teachers and the surrounding community. If our relationship with the surrounding community could be poor no assistance we could obtain from our neighbors. For example, due to good relationship with TANAPA, they built a dormitory for girls students to stay (Interviewee 2, $6^{\text {th }}$ August, 2020).

The conceptual framework of the study also indicates that, students' council is responsible for encouraging healthier relationship among teachers and students in the process of teaching and learning. This helps to promote a sense of ownership, ethics of care and cooperation between students and teachers in a school. Therefore, through students councils, schools are made peacefully and health contexts for the growth of new minds for a successful society.

\section{CONCLUSION}

The study assessed the involvement of students' council; it mainly concentrated on the key roles and the available opportunities to empower students' council. The findings mean that students' council is the chief part in enforcing school rules, regulation and orders in such a way that schools cannot withstand students' disciplinary cases without support from this council. Thus, schools should embrace and employ students' council in managing students' discipline and other school activities. In other words, schools management should do the best to empower and monitor students' council so that its fruits can be determined and felt by all school members.

\section{RECOMMENDATIONS FOR ACTION}

This study concentrated on examining the roles played by students' council in management of students' discipline. The findings of this study have implications to policy makers, heads of schools, teachers and students.

\section{Recommendations for Policymakers}

This study informs policy makers that there is a need to review and develop new policies to truly officialize the existence, formation and functioning of democratic students' council in secondary schools. This may help to schools democratic select members of the students' council that can work efficiently for the welfare of students and the school as a whole.

\section{Recommendations for Heads of Schools}

This study has an implication on heads of schools that they should plan and implement regular trainings in form of seminars and workshops to instill leadership skills among students' leaders to lead the students' council effectively. This can be an important channel for preparing efficient leaders for sustainable development of our national and the world community as a whole.

\section{Recommendations for Teachers}

There is a notion that teachers are second to none. Therefore, teachers are mostly available in schools all the time. Thus, this study has implication to teachers that they should render effective and productive collaboration and support to members of the students' council so that they reach their destination of making schools with ethical people.

By doing so students leaders who constitute the students council can fill the sense of togetherness, ownership and being valued in such a way that they can withstand some of the challenges by being aware that their great supporters (teachers) are with them.

\section{Recommendations for Students}

This study has implications to students that they should consider and value members of the students' council as their savior not enemies. Theirs, they should effective give them support and collaborate fully in making sure that schools natures people that embrace virtues.

\section{Recommendations for Implication Members of Students' Council}

The study findings show that students' council is powerful in enforcing school rules towards achievement of desired students' discipline. Therefore, the members of this council should consider their involvement in decision making as opportunities to success of their schools. They should establish effective forums to discuss their strengths and areas of weaknesses as well as strategies for success. 


\section{LIMITATIONS TO THE STUDY}

This study was conducted to find out the roles and the extent to which students' council is involved in the management of students' discipline. Despite this study being successful in obtaining relevant information to answer the research questions it was limited to students' council, a small geographical locations and few schools were sampled. Thus, the findings of this study are limited to the perception of only few participants and therefore its generalization may be questionable.

Methodologically, this study left behind observation and document analysis as methods of data collection. If these methods had have been used perhaps could provide vivid information to enrich the information provided by participants on whether disciplinary meetings involve members of the students council and the way students leaders behave during discharging their roles.

Likewise, some key informants like heads of schools were not Emily found and were not able to speak through the mobile phones. These were replaced by deputy heads of schools in such a way that the information given may not be as strong as it could be given by the head of school himself / herself who is entitled to oversee all school matters. Thus, this study bears information or data that may be not valid and reliable though it emanates from similar school environment.

\section{REFERENCES}

[1] Adams, K.A. \& Lawrence, E. K. (2015). Research methods, statistics and applications. Los Angeles, LA: SAGE Publishing, Inc., Kenya.

[2] Alexander, B, G. (2017). Student voice initiative: Exploring Implementation Strategies, USA. Theses and Dissertations, 12(1).

[3] Amoah, A.S., Francis, M.O., Laryea, P. \& Abena, G. (2015). Managing school discipline: The Students' and Teachers' Perception on Disciplinary Strategies. British Journal of Psychology Research, 3(2), 1-11.

[4] Asare, S. A. Mensah, O. F., Prince, L., and Gyamera, A. (2015). Managing School discipline: The students' and teachers' perception on disciplinary strategies. British Journal of psychology Research, 3(2), 1- 11.

[5] Cato, N. (2018). Student voice in secondary schools: Purpose, Value and Characteristics (Master's dissertation), United Institute of Technology, New Zealand). 112(2), 105 132.
[6] Charles, C.M., \& Mertler, C. A. (2002). Introduction to educational research ( $4^{\text {th }} \mathrm{ed}$.) Boston:

Ally \& Bacon.

[7] Charles, J. (2015). Contribution of supervision on improvement of academic performance in Tanzania primary schools: A case of Nyamagana Municipal (Master's dissertation). Saint Augustine University of Tanzania, Mwanza, Tanzania.

[8] Creswell, J. W. (2014). Research design: Qualitative, Quantitative and Mixed Methods Approaches. (4 ${ }^{\text {th }}$ ed.). New Delhi. Sage Publication Ltd.

[9] Demir, S. B., \& Pismek, N. (2018). A convergent parallel mixed-methods study of controversial issues in social studies classes: A clash of ideologies. Turkey. Theory \& Practice, 18, 119-149. http://dx.doi.org/10.12738/estp.2018.1.02981

[10] Ezzy, D. (2002). Qualitative analysis, practice and innovation. New Zealand: Allen \& Unwin Ltd. FE. Peacock Publisher. Inc.

[11] Glriebler, U., Nowak, P. (2011). Students councils: A tool for health promoting schools?

[12] John, K. A. (2017). Factors leading to indiscipline in secondary schools in Siha District Council, Tanzania (Master's dissertation). Open University of Tanzania, Dar Es Salaam, Tanzania.

[13] Kamau, A. (2017). Influence of students' council involvement in management of students discipline in public secondary schools in Naivasha Sub- County, Nairobi, Kenya.

[14] Kambuga,Y. \& Omllo, A. (2017). Understanding students' leadership role and challenges in secondary schools in Tanzania. Asian Research Journal of Arts and Social Sciences, 2(3), 1-10.

[15] Kennedy, O. (2018). Managing students discipline through students leaderships in Kenyan secondary schools. European Journal Research and Reflections in Educational sciences, 69 (2), 1-9.

[16] Kothari, C.R. (2004). Research methodology: Methods \& techniques ( $2^{\text {nd }}$ ed.). New Delhi, India; New Age International (P) Limited.

[17] Kyalo, K. D. (2017). Influence of student councils, involvement in school governance on students' discipline in public secondary schools in Kathonzweni Sub County, Kenya (Master's research project, University of Nairobi, Kenya).

[18] Lansdown, G. (2001). Promoting children's participation in democratic decision- making. Siena: Arti Grafiche Ticci.

[19] Leung, L. (2015). Validity, reliability and generalization in qualitative research. J Family Med Prim Care, 4(3), 324 327.

[20] Mboyonga, E. (2018). The role of student representative councils in curbing students' riots in selected secondary schools of Chipata District, Zambia. International Journal of Humanities Social Sciences and Education (IJHSSE), 5(3), 36- 43. 
[21] Mgaya, E., \& Kamugisha, D. K.(2019). An introduction to educational psychology: A practical guide. Mwanza, Tanzania: Tridax Africa Company Limited.

[22] Mnubi, M. G. (2015). Improving the quality of basic education through the use of gender-sensitive student councils: Experience of six selected districts in Tanzania. Journal of Learning for Development (JL4D), 4(2), 161-168.

[23] Mukiti, M. T. (2014). Role of students' council in secondary schools management in Mwingi Central District, Kitui County, Kenya (Master's research project), Kenyatta University, Kenya.

[24] Mulengeki, F. (2014). The school level human factor in education reforms, the case of the early $21^{\text {st }}$ century education reforms in Tanzania. Saarbruken. Deutsebland. Omin Scriptum Gmbh \& CO. KG.

[25] Murage, L. M, Njoka, J. \& Gachahi, M. (2019). Challenges faced by student leaders in managing student affairs in public universities in Kenya. International Journal of Education \& Literacy Studies, 7(1), 1 - 7.

[26] Murage, L. M. (2014). Challenges facing student councils on management of discipline in secondary schools and measures put in place in Kirinyaga East District, Kenya. IOSR Journal of Humanities and Social Sciences (IOSR - JHSS), 22(7), 40 -51 .

[27] Murage, L. M., Mwaruvie, J., \& Njoka, J. (2017). Influence of student councils on management of discipline in secondary schools in Kirinyaga East District, Kenya. IOSR Journal of Humanities and Social Science (IOSR - JHSS) 22(7), 52 - 63.

[28] Namala, S.J. (2015). The effectiveness of motivation on employees' performance in public organization: A case study at Lushoto District Council (Master's dissertation). Open University of Tanzania, Tanzania.

[29] Nandeke, E. (2017). Student council participation in the management of discipline in public secondary schools in Teso North,sub-country, Busia country, Kenya (Master's thesis), Moi University, Kenya.

[30] Nekesa, M. C. (2018). Role of students' councils in enhancing discipline in public secondary schools in Likoni Sub-County Mombasa County Kenya (Master's research project), Kenyatta University, Kenya.

[31] Nishiyama, K. (2017). Deliberators, not Future citizens: Children in Democracy. Journal of Public Deliberation, 13(1). Retrieved from https://www.publicdeliberation.net/jpd

[32] Oso,Y.W. \& Onen, D. (2016). A general guide to writing research proposal and report: A handbook of beginning researchers, $\left(5^{\text {th }}\right.$ edn), Nairobi, Jomo Kenyata Foundation.

[33] Pacho, T. (2017). Service - learning in higher education in Zimbabwe (doctoral dissertation, University of Humburg, German).

[34] Sharma, G. (2017). Pros and Cons of different sampling techniques. International Journal of Applied Research, 3(7), $749-752$.
[35] Shija, M. (2016). Raising students'voices: School councils in Tanzania supporting young people to claim their education rights. Oxfam, Tanzania.

[36] URT, (2014). Baraza la watoto wa jamhuri ya muungano wa Tanzania: Mwongozo wa uundaji wa mabaraza ya watoto ngazi ya kijiji, kata, wilaya na mikoa, DSM.

[37] Usman, H. (2016). Impact of students' indiscipline on the management of secondary schools in Kogi - East Senatorial District. International Journal of Education and Research, Kogi State University, Nigeria, 6(4).

[38] Wallach, A. C., Ramsey, S. B., Lowry, K. L., and Colpland, M. (2006). Students voice: Tapping the potential relationships, relevance and rigor, Washington DC, USA.

[39] Whitty, G., \& Wisby, E. (2007). Whose voice? An exploration of the current policy making in pupil involvement in decision making. England.

[40] Williams, M. K. (2017). John Dewey in $21^{\text {st }}$ Century. Journal of Inquiry and Action in Education, 9(1), 91- 102.

[41] Woods (2005). Democratic leadership in Education. London, Paul Chapman Publishing.

[42] Yin, R. K. (2011). Qualitative research from start to finish. New York, NY: The Guilford Press.

ISSN: 2456-7620 